\section{Laboratory Notes}

\section{J. Appl. Cryst. (1982). 15, 577}

\section{A systematic method for aligning double-focusing mirrors}

A comprehensive description of an alignment procedure for double-mirror (Franks) cameras is presented.* It is intended to serve as a practical laboratory guide. The method is summarized in a flow chart and illustrated by beam photographs and intensity profiles. Principals underlying the method are explained. Detailed procedures are given for the initial alignment of the mirrors, optimizing the focus and shape of the beam, adjusting the reflection and takeoff angles, defining and guarding the beam, and monitoring the process with a fluorescent screen, photographs and an $X$-ray counter. In the double-mirror sysstem, which was originally constructed by Kirkpatrick \& Baez (1948) and developed by Franks (1955), X-rays emitted from a localized source can be focused by total reflection from two orthogona curved mirrors to form small intense beams with narrow angular divergence. Double-mirror cameras are now commonly used for diffraction studies requiring high order-to-order resolution.

WALTER C. PHILLIPS IVAN RAYMENT

Rosenstiel Basic Medical Sciences Research Center

Brandeis University

Waltham

Massachusetts 02254 USA

(Received 2 November 1981; accepted 1 May 1982)

References

Franks, A. (1955). Proc. Phys. Soc London Sect. B, 68, 1054-1064.

Kirkpatrick, P. \& Baez, A. V. (1948). J Opt. Soc. Am. 38, 766-774.

*The complete description of this procedure has been deposited with the British Library Lending Division as Supplementary Publication No. SUP 36934 (22 pp.). Copies may be obtained through The Executive Secretary, International Union of Crystallography, 5 Abbey Square, Chester $\mathrm{CH} 12 \mathrm{HU}$, England.

\section{Crystallographers}

\section{J. Appl. Cryst. (1982). 15, 577}

This section is intended to be a series of short paragraphs dealing with the activitios of crystallogparagraphs dealing whithe activilis of crystallographers. such as their changes of position, promotions, assumption ar signifcant now duties. honours, esc
Editorial Board, should be sent to the Executive Secre tary of the International Union of Crystallography (J. N. 政 Square, Chester $\mathrm{CH} 12 \mathrm{HU}$. England).

Dr Julio Garrido, who died on 14 May 1982 at the age of 70 , was one of the pioneers in X-ray crystallography in Spain. Professor S. Garcia-Blanco writes that having achieved his doctorates in Natura Sciences and in Physical Sciences, he published his first book Los Rayos $X$ y la estructura fina de los cristales in 1946. The first paper published in Acta Crystallographica in 1948 Observations sur la Diffraction des Rayons $X$ par les Cristaux de $\mathrm{ClO}_{3} \mathrm{Na}$ was by Garrido. He carried out a large number of fundamental X-ray investigations. He was Adjunct-Director of the Documentation Scientific Centre of CNRS (France) and Vice-President of the Societé française de Cristallographie. $\mathrm{He}$ collaborated in the preparation both of International Tables and Structure Reports for the International Union of Crystallography. He was elected academician of the Real Academia de Ciencias Exactas, Fisicas y Naturales of Spain. His greatest interest in crystallography was widely known and appreciated in Latin American countries where he dedicated many years of study and research. He was Director of the UNESCO Technical Assistance agency to Latin America in Montevideo (Uruguay). By his death crystallographers have lost an invaluable colleague.

Professor C. N. R. Rao, Indian Institute of Science, Bangalore, has been elected a Fellow of the Royal Society of the United Kingdom.

In March 1982 Dr Ajit Ram Verma, who is well known for his manifold contributions in the field of crystal growth and polytypism, retired from active service as Director of the National Physical Laboratory, New Delhi, India, which he headed for 17 years.

\section{Notes and News}

Announcements and other items of crystallographic interest will be published under the heading at the discretion of the Editorial Board. The riotes (in duplicate) should be sent to the Executive Secretary of the International Union of Crystallography (J.N. King. International Union of Crystallography, 5 Abbey Square, Chester $\mathrm{CH} 12 \mathrm{HU}$. England).

\section{J. Appl. Cryst. (1982). 15, 577}

\section{Formation of the British Crystallographic Association}

The following note by Professor D. M. Blow, Chairman of the UK National Committee for Crystallography, has been reprinted from the Royal Society News, by kind permission of the Royal Society:
For many years the organisation of crystallography at a national level in the UK has been split between a number of scientific societies. The two largest groups are the Crystallography Group of the Institute of Physics and the Chemical Crystallography Group of the Royal Society of Chemistry, but a number of other societies cover crystallographic aspects of metallurgy, materials science, geology and biophysics. The UK Crystallographic Council provided a loose link between groups of crystallographers but it could not provide a speedy, collective response of UK crystallographers on, for instance, draft Health and Safety Executive legislation or EEC directives. Nor did its structure allow it to undertake activities with financial responsibilities, such as the organisation of a European Crystallographic Meeting in the UK

The British National Committee for Crystallography, in addition to its duties as corresponding body to the International Union of Crystallography, provided a forum where matters concerning crystallography in the UK could be discussed. But it was not appropriate for it to deal with internal national matters. On the initiative of the National Committee, a working party was set up with the aim of establishing a new independent body covering all areas of crystallographic interest, to present the views of crystallographers collectively, to organise meetings of a crystallographic nature and to act as a centre for the dissemination of information on crystallography both within the profession and to a wider audience.

This initiative gained strong support. Particular help was given by the committees of the two largest groups in devising a system for incorporating their activities into the new Association. The British Crystallographic Association was inaugurated on 5 April 1982 at a meeting in Durham. The elected Officers of the new body are: President: Sir David Phillips, Professor of Molecular Biophysics in the University of Oxford and Biological Secretary, Royal Society; Vice-President: Professor Dorothy M. Hodgkin, Emeritus Professor in the University of Oxford; Treasurer: Professor C. A. Taylor, Professor of Physics at University College. Cardiff, in the University of Wales; Secretary: $\mathrm{Dr}$ A. C. Skapski, lecturer in physical chemistry at the Imperial College of Science and Technology, London.

\section{J. Appl. Cryst. (1982). 15, 577-578}

\section{European Crystallographic Committee Cooperation Schemes}

The European crystallographers, through the European Crystallographic Committee, invite colleagues in developing countries to join in co-operation schemes. 